IRA-International Journal of Management \& Social Sciences

ISSN 2455-2267; Vol.06, Issue 02 (2017)

Pg. no. 268-285

Institute of Research Advances

https://research-advances.org/index.php/RAJMSS

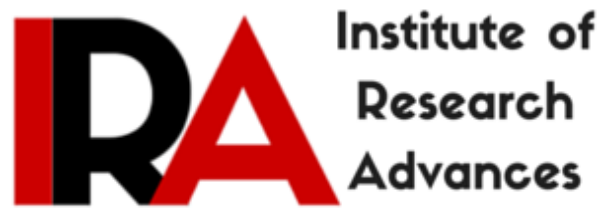

\title{
SHG Federations as Livelihood Support Organizations
}

\author{
T. Navin, N. Srinivasa Rao, Shashank Singh, Dr. Rajendra Singh Gautam \\ Lead Faculty, Institute for Livelihood Research and Training, Hyderabad, Telangana, \\ India.
}

Type of Review: Peer Reviewed.

DOI: http://dx.doi.org/10.21013/jmss.v6.n2.p11

\section{How to cite this paper:}

Navin, T., Rao, N., Singh, S., \& Gautam, R. (2017). SHG Federations as Livelihood Support Organizations. IRA-International Journal of Management \& Social Sciences (ISSN 2455-2267), 6(2), 268-285. doi:http://dx.doi.org/10.21013/jmss.v6.n2.p11

(C) Institute of Research Advances

(c) EY-NO

This work is licensed under a Creative Commons Attribution-Non Commercial 4.0 International License subject to proper citation to the publication source of the work.

Disclaimer: The scholarly papers as reviewed and published by the Institute of Research Advances (IRA) are the views and opinions of their respective authors and are not the views or opinions of the IRA. The IRA disclaims of any harm or loss caused due to the published content to any party. 


\section{ABSTRACT}

The last two decades has witnessed a phenomenal growth in the number of Self Help groups (SHGs) and SHG federations in India. There were an estimated 1, 78,664 SHG federations in Indial during 2013-14. SHG federations emerged as important institutions to take over the functions formerly provided by SHG promoting organizations. Placed in a situation where small size of SHGs and their limited financial and human resourcesdid not allow it to deal with larger financial and non-financial, livelihood issues affecting their women members, SHG federations were to address this gap. It was to go beyond being mere financial intermediaries to also become livelihood promotion organizations. The paper argues that while SHG Federations have emerged as financial intermediaries, its role as livelihood support organizations is still a question mark. The study looks at the role of SHG federations as livelihood support organizations.

\section{Introduction}

Poverty has been a major issue in India since independence. A number of experiments were made during the last century to find solutions to poverty. Various experiments were made at finding solutions which were technical, financial, institutional, skill based, infrastructural, political and rights based and others. Large scale projects, large bureaucracies, large scale developmental institutions, programs and schemes were seen as a means which would address poverty in the country. A major transition in development thinking was made when people's own capacities through voluntary efforts and their own self-help aided through state and civil society support were recognized as important processes through which the poor can come out of poverty. A major experiment which attracted large scale attention of development players was the concept of self-help groups (SHGs). SHGs were seen as a means of enhancing financial inclusion, poverty alleviation and women empowerment. SHG movement has established itself in India. SHG federations can be seen as a continuation of growth of SHG movement.

The present paper looks into SHG federations as a livelihood support organizations based on a field study carried out in Tamil Nadu and Madhya Pradesh. The first section traces the backdrop and evolution of the concept of SHG federations in India. The second section discusses the objectives and methodology of the SHG federation study. The third section discusses the profile of the SHG federations in the study states. The fourth section discusses the key findings of the study. The fifth section deals with key policy recommendations.

\section{Section 1: Background and Evolution of SHG Federations in India}

Beginning with grassroots experiments which were taken up in the late 1970s and 80-s, SHG-Bank linkage program was adopted as a poverty alleviation tool in the country by National Bank for Agriculture and Rural Development (NABARD) in 1992. SHG movement grew in the country especially through the efforts of NGOs, National Rural Livelihood Mission (NRLMs) and State Rural Livelihood Mission (SRLMs) in the country. Starting from a modest scale as a pilot in the year 1992, the SHG-Bank linkage programme has turned into a solid structure with more than 79.60 lakh savings-linked Self Help Groups (SHGs) covering over 10.3 crore poor households as on 31 March 2012. The total savings of these SHGs amounted to 6,551.41 crore. The number of credit-linked SHGs under the programme stood at 43.54 lakh (NABARD, 2013). The following table depicts the growth of SHGs under SHG Bank linkage program.

\footnotetext{
${ }^{1}$ Information captured by Andhra Pradesh MahilaAbhivruddhi Society (APMAS)
} 
Table 1.1: Growth Trends in SHG-Bank linkage

\begin{tabular}{|l|l|l|l|l|l|l|l|}
\hline Particulars & 2006 & 2007 & 2008 & 2009 & 2010 & 2011 & 2012 \\
\hline $\begin{array}{l}\text { No. of SHGs } \\
\text { provided with bank } \\
\text { loans }\end{array}$ & $2,238,565$ & $2,924,973$ & $3,625,941$ & $4,224,338$ & $4,587,178$ & $4,813,684$ & $4,354,567$ \\
\hline $\begin{array}{l}\text { Average disbursed } \\
\text { loan per group in Rs. }\end{array}$ & 37,574 & 44,343 & 46,800 & 74,000 & 115,820 & 122,744 & 144,086 \\
\hline $\begin{array}{l}\text { Outstanding loans } \\
\text { Rs. (billion) }\end{array}$ & 123.66 & 169.99 & 226.76 & 272.66 & 306.19 & 363.41 \\
\hline
\end{tabular}

(Source: Status of Microfinance in India Report, NABARD)

An important development in the SHG movement is the emergence of SHG federations. SHG federations emerged to provide critical financial and non-financial support to SHGs. The main objective of federating the SHGs is to make them stronger and ensure their organizational, operational and financial sustainability. The earliest SHG federation was formed by the then Professional Assistance for Development Action (PRADAN, presently the DHAN Foundation) in Tirupati in 1992 and later in Madurai, soon followed by Kudumbhashree Panchayat Samithy (CDS), Alappuzha in 1993 and Mysore Resettlement and Development Agency (MYRADA) in 1996 (Thankha, 2010).Now there are more than1, 70,000 primary federations, 7,091 secondary federations and 66 tertiary federations in the country. The following table depicts the distribution of SHG federations in the country.

Table 1.2: State wise Promotion of SHG Federations as on March 2013

\begin{tabular}{|c|c|c|c|c|c|}
\hline & \multirow[b]{2}{*}{ Region } & \multicolumn{3}{|l|}{ Number of } & \multirow[b]{2}{*}{ Total } \\
\hline & & $\begin{array}{l}\text { Primary } \\
\text { Federations }\end{array}$ & $\begin{array}{l}\text { Secondary } \\
\text { Federations }\end{array}$ & $\begin{array}{l}\text { Tertiary } \\
\text { Federations }\end{array}$ & \\
\hline \multirow[t]{2}{*}{$\mathbf{A}$} & Northern Region & & & & \\
\hline & Region-Total & 15715 & 40 & 1 & 15756 \\
\hline \multirow[t]{2}{*}{ B } & North Eastern Region & & 40 & & \\
\hline & Region-Total & 1501 & 8 & $\mathbf{0}$ & 1509 \\
\hline \multirow[t]{2}{*}{$\mathrm{C}$} & Eastern Region & & & & \\
\hline & Region-Total & 45150 & 3210 & 41 & 48401 \\
\hline \multirow[t]{2}{*}{ D } & Central Region & & & & \\
\hline & Region-Total & 7070 & 149 & $\mathbf{0}$ & 7219 \\
\hline \multirow[t]{2}{*}{$\mathbf{E}$} & Western Region & & & & \\
\hline & Region-Total & 11612 & 319 & $\mathbf{0}$ & 11931 \\
\hline \multirow[t]{2}{*}{$\mathbf{F}$} & Southern Region & & & & \\
\hline & Region-Total & 90451 & 3365 & 24 & 93840 \\
\hline \multirow[t]{4}{*}{$\mathbf{G}$} & Union Territories & & & & \\
\hline & Pondicherry & 8 & 0 & 0 & 8 \\
\hline & Region-Total & 8 & $\mathbf{0}$ & $\mathbf{0}$ & 8 \\
\hline & Grand Total & 171507 & 7091 & 66 & 178664 \\
\hline
\end{tabular}

(Source: APMAS) 
The SHG federations are predominant in West Bengal, Telengana, Andhra Pradesh, Kerala and Tamil Nadu states and promoted under Mutually Aided Cooperative Societies Act in Andhra Pradesh, Kudumbashree program in Kerala, Vahndhu Kaatvom and Mahalir Thittam programs in Tamilnadu. PRADAN, MYRADA, DHAN and CARE are the prominent NGOs that promote SHG federations in large scale.

There are various types of federations. Financial federations provide finance - related services such as saving, credit, insurance and money transfer, while non-financial federations provide sector development, livelihood development and social development services. There is, however, a third category called multipurpose federations, which undertake at least one financial and one non-financial function. Most of the federations in the country belong to the multi-purpose category as they provide a range of products and services thus following a 'credit-plus' approach rather than 'credit only' approach. The federations perform four broad categories of functions viz., financial functions, business development / livelihood services, strengthening or supporting services for SHGs, and social or developmental initiatives. The tendency of federations however largely is to provide financial services. Focus on livelihood services is limited. It is with this purpose to understand the role of federations in providing livelihood services, the study was taken up.(Dr. Wolfgang Salomo, December 2012)

\section{Section 2: Methodology}

A total of 20 SHG federations were selected from two states namely Madhya Pradesh and Tamil Nadu. 10 federations each were selected from the two states. The study was based on data collection carried out with SHG federations, SHGs and SHG members during the period February to June 2014. For each sample federation, 10 SHGs forming part of the federation and 5 falling outside the federation were studied in the case of Madhya Pradesh. In the case of Tamil Nadu, 5 SHGs which were active and 5 SHGs less active in the federation were taken up for the study. Thus a total of 20 federations, 200 SHGs and 800 SHG members were covered across both the states. The sample provided adequate representation to different regions, agro-climatic zones, legal entities, age and level of federations. Across both the states about 18 districts and 15 promoting agencies were represented. The promoting agencies included both the NGOs and the Government.

The overall objective of the study was to assess the role of SHG federations as livelihood support organizations in creating livelihood impact among SHG members and to recommend means for strengthening its role towards the same.

Stratified random sampling process was adapted to select sample of federations. State was divided into regions. An attempt was made to cover as many districts and as many promoting agencies as possible spread across different regions in the states. Hence across both the states about 18 districts and 15 promoting agencies were represented. The promoting agencies included both the NGOs and the Government. The sample of federations in Madhya Pradesh covered all the important regions namely Satpura region, Malwa region, Nimar region and Bundhelkhand region. An important parameter for selection of regions also included representativeness of tribal / non-tribal, rural / urban areas. The sample of federations in Tamil Nadu covered all the geographical locations namely Southern, North western and north eastern and Western Zones. 
The sample federations that were studied included the following.

\begin{tabular}{|c|c|c|c|}
\hline $\begin{array}{l}\text { S. } \\
\text { No. }\end{array}$ & Name of the Federation & $\begin{array}{l}\text { Promoting } \\
\text { Agency }\end{array}$ & District \\
\hline 1 & NamanSakhSahakaritaMaryadit (NSSM) & NamanSewaSamiti & Betul (Satpura) \\
\hline 2 & Nari Shakti MahilaSangh (NSMS) & Tejaswini & Balaghat (Malwa) \\
\hline 3 & SamriddhiSakhSahkaritaMaryadit (SSSM) & MPRLP / NRLM & Barwani (Nimar) \\
\hline 4 & SakhiManch & Samavesh & Dewas (Nimar) \\
\hline 5 & BunkarVikasSanstha (BVS) & UNIDO & $\begin{array}{l}\text { Ashoknagar } \\
\text { (Malwa) }\end{array}$ \\
\hline 6 & Narmada MahilaSangh (NMS) & PRADAN & $\begin{array}{l}\text { Hoshangabad } \\
\text { (Satpura) }\end{array}$ \\
\hline 7 & TejaswaniNariChetnaSangh (TNCS) & NIWCYD & Dindori (Malwa) \\
\hline 8 & Shakti MahilaSangh (SMS) & BASIX & Jabalpur (Satpura) \\
\hline 9 & AparajitaMahilaSakhSahkaritaMaryadit & FWWB & Indore (Nimar) \\
\hline 10 & BundhekhandMahilaSakhSahkaritaMaryadit & SEWA & $\begin{array}{l}\text { Chhatarpur } \\
\text { (Bundhelkhand) }\end{array}$ \\
\hline \multicolumn{4}{|c|}{ Tamilnadu } \\
\hline 11 & Palma Federation & PWDS & $\begin{array}{l}\text { Kanyakumari } \\
\text { (Southern) }\end{array}$ \\
\hline 12 & VikramangalamPanchayatLevel federation & MahalirThittam & Madurai (Southern) \\
\hline 13 & Sri Janajagruti Resource Center (SJRC) & MYRADA & $\begin{array}{l}\text { Krishnagiri (North } \\
\text { western) }\end{array}$ \\
\hline 14 & Varatupatti Cluster Level Federation (VCLF) & IVDP & $\begin{array}{l}\text { Krishnagiri (North } \\
\text { western) }\end{array}$ \\
\hline 15 & Oddapatty PLF & MahalirThittam & $\begin{array}{l}\text { Salem (North } \\
\text { western) }\end{array}$ \\
\hline 16 & $\begin{array}{l}\text { KadayampattiVattaraPengalMunneraNalaSangham } \\
\text { (KVPMS) }\end{array}$ & World Vision & $\begin{array}{l}\text { Salem (North } \\
\text { western) }\end{array}$ \\
\hline 17 & InnuirGramaSangham (IGS) & MSSRF & $\begin{array}{l}\text { Puducherry (North } \\
\text { eastern) }\end{array}$ \\
\hline 18 & AasurPaguthiAdharMaiyam (APAM) & Kalvi Kendra & $\begin{array}{l}\text { Villupuram (North } \\
\text { eastern) }\end{array}$ \\
\hline 19 & Jaihind federation & REAL & $\begin{array}{l}\text { Cuddalore (North } \\
\text { eastern) }\end{array}$ \\
\hline 20 & Kemmarapalli PLF & Good Shepherd & $\begin{array}{l}\text { Coimbatore } \\
\text { (Western zone) }\end{array}$ \\
\hline
\end{tabular}

Factsheet and Interview schedules were administered for data collection with SHG federation. The factsheet covered quantitative details related to the federation. These were related to background information, outreach of the federation, financial performance of the federation, financial products, social services, livelihood services, funding status and nature of enterprises supported. The interview schedule aimed at eliciting qualitative responses from the federation staff, governing board and management. These were related to origin of the federation, development objectives, livelihood interventions, structure and systems, governance, financial and operational health and incremental health. Similarly there were factsheets and interview schedules administered for SHGs which touched upon financial details, financial and livelihood services, public services, internal management systems, functional autonomy etc. 
Structured Questionnaire was administered with SHG members. It covered details in relation to social profile of SHG members, livelihood profile, membership in associations, reason for membership, services received from SHG federation; linkages established with institutions, satisfaction with SHG federation services, incremental benefits received through SHG federations.

Data collection was carried out by a seven member team during February to June 2014 assisted by 10 field investigators. The collected data was entered into MS-Excel. It was imported into SPSSS and analyzed. Cross tabulations were done to understand the co-relations between different variables. Fact sheets, field notes, SPSS analysis were used to arrive at the key points and develop the report.

\section{Section 3: Profile of SHG federations in the study States}

Legal

In Madhya Pradesh, five federations taken up for study were under the Madhya Pradesh Swayatta Sahakaritha Adhiniyam (1999) Act and five federations were registered under Societies Registration Act 1973. In Tamil Nadu, three SHG federations were registered under the Tamil Nadu Charitable Trust Act, five federations were registered under Tamil Nadu Societies Registration Act 27 of 1975 and two federations were registered under Mutual Benefit Trust Act.

\section{Mission}

The mission of all the SHG federations had to do with poverty reduction, livelihood promotion through financial inclusion of the poor rural women. While the federations had this mission, the primary focus tended to be on financial inclusion. In the case of Bunkar Vikas Sanstha (BVS), the target clientele were the poor women from the weaving community.

\section{Outreach}

In Madhya Pradesh, the federations had outreach ranging from five villages to 243 villages, 13 groups to 1,050 groups and 119 members to 9,933 members. In Tamil Nadu, the federations had outreach ranging from five villages in one panchayat to 191 villages in 142 panchayats, 30 SHGs to 582 SHGs and 460 members to 8,224 members.

Products and Services

In both the states, the SHG federations offered a range of financial and non-financial services. The financial services included savings, credit and insurance. Some federations offered market linkage, value chain services etc. While non-financial services were also offered by federations, the focus tended to be on financial services and that too specifically on credit services. Livelihood services were either absent or even if existed were negligent. All the federations are facilitating to arrange bank linkages to their member SHGs.

\section{Collaborations}

The SHG federations had established collaborations with a number of development players - apart from their promoting agencies. These included civil society organizations such as Indian Grameen Services, Namansevasamithi, PRADAN, Samavesh, National Institute of Women, Child and Youth Development (NIWCYD), Bhartiya Samruddhi Investments and Consulting Services Ltd. (BASIX), Self-Employed Women Association (SEWA), M S Swaminathan Research Foundation (MSSRF), MYRADA, Integrated Village Development Project (IVDP), World Vision, Kalvi Kendra, Palmyrah Workers Development Society (PWDS); government agencies such as project Tejaswini, Madhya Pradesh Rural Livelihoods Program (MPRLP), Tamil Nadu Corporation for Development of Women (TNCDW), Department of Rural Development and Agriculture; banks and financial institutions such as Cholamandalum, Federation of Women's World Banking (FWWB), Industrial Development Bank of India (IDBI), State Bank of India 
(SBI), Indian bank, Rashtriya Mahila Kosh (RMK), Small Industries Development Bank of India (SIDBI), ICICI bank, AXIS bank, Narmada Jhabua Grameen Vikas bank; insurance companies like such as Life Insurance Corporation of India (LIC), Bajaj, Oriental insurance, and Birla sun life etc. The collaborations were with the purpose of gaining access to finance, capacity building and technical inputs from the collaborating agencies.

\section{Governance}

The federations largely had a three tier structure with SHGs at the bottom, village level committees and federations. The composition of board members varies from 11 to 15 members. The board members were mostly democratically or unanimously elected. The issues related to governance which affected the federations included non-cooperativeness of Board, continuing influence of promoter agency, low capacities of some board members, factionalism, lack of vision by leaders to look beyond financial services, non-compliances with statutory processes especially for the newly formed federations. Some positive trends also observed included relative autonomy of board vis-à-vis promoting agency, wide experience and knowledge of board members etc.

Management systems

Except Panchayat Level Federations (PLFs), all the federations have three tier federations. These federations are at varied level in relation to operational and documentation systems. Manual accounting is seen in all the PLFs and was computerized accounting system in three tier federations. In most of the cases, accounting processes were being assisted by promoting agencies. Professional staff was either deputed from the promoting agencies in case of MSSRF, MYRADA and IVDP or hired wherever necessary. Internal control systems were however, found to be weak.

\section{Sustainability}

The federations had issues related to sustainability. The financial sustainability of the federation is dependent on the reputation of the promoting agency. For instance, the federations promoted by MYRADA, IVDP are sustainable and MSSRF promoted federation is transforming itself. The other federations promoted by TNCDW are struggling to attain sustainability. While some federations were performing well in relation to financial, institutional and social sustainability - the others while doing well on one dimension were lagging behind on other parameters.

Low membership fee, irregular periodic subscription, low savings amount were some of the factors for lower financial sustainability. Wherever federations were sustainable, they were receiving frequent / continual support from the donors.

\section{Section 4: Findings of the Study}

The study revealed that membership in SHG federations had certain advantages than those without membership. The benefits were in relation to financial benefits, livelihood benefits, non-financial benefits and social empowering effects.

\section{Federated members have better access to financial services}

Members of the SHG federation were advantageously placed in accessing loans as per their loan requirements. This was in contrast to non-federated SHG members whose ability to access loans was lower. Loan amounts for non-federation members were found to be insufficient in comparison to federated members. Moreover, those with membership in SHG federations had access to wider set of financial services such as production loans, consumption loans, enterprise loans and others. Federated members had a better coverage under insurance. There were a few who were also under social security 
coverage under federation's life security funds. Some were protected against fire accident to houses. Widow children scholarship fund was also created in one federation.

The federated members are advantageously placed in relation to services - such as receiving door step credit services, revolving fund assistance, accessing insurance services, value chain services, input-output linkages, skill development services and capacity building services which non-members did not receive. Members after being part of the federation were also found to have moved up the value chain in terms of their engagement in livelihood.

\section{Federated members received larger non-financial benefits}

Federated members received larger non-financial benefits. Capacity building by federations resulted in better local level leadership skills. They had higher awareness on the roles and responsibilities as members of SHGs and SHG federations. Federated SHGs were offering livelihood services such as by BVS, SJRC and VCLF which were further contributing to income-enhancement.

\section{Federated members experienced more well-being than Non-federated members}

Membership in federations also resulted in greater well-being benefits. E.g. members associated with NSMS reported that they have better access to health services. Members also confirmed improvement in children's education. Activities by NSMS, Kali Kendra and VCLF in advocacy of rights and entitlements and action against domestic violence was promoting household well-being. Power of collectives was bringing down social evils such as in NSMS area where domestic violence and alcoholism had come down. Instances of growing confidence of members, accessing higher education of their children and better health facilities were also seen. A few have also distributed old-age pension and NREGA cards.

\section{Federated members graduated to avail higher levels of services after joining federation}

Members benefited after membership with federation. Prior to membership, they were all engaged in only group-level savings and internal credit but no external credit support. After being federated the members have been able to gain a higher loan amount. They also started having access to insurance services. There were instances of members graduating into higher levels of value chain. E.g., in handloom value chain certain members took up activities right from procurement of yarns to marketing. This had a direct impact on their levels of confidence in venturing and running business.

\section{Division between financial and livelihood functions is preventing graduating to higher levels}

A division of responsibilities is seen in financial and livelihood services. While the federation focuses purely on financial intermediation, livelihood services are often provided by promoting agency. E.g. Namansewasamiti has projects related to organic farming. IGS and APAM are offering agriculture and agri allied extension services. With divisions such as each type of federations focusing on specialized service - financial, livelihood or social empowerment, the other services are seen to be missing. It is only purely livelihood focused federations which tend to have major focus on livelihoods e.g., BVS.

\section{Federated members experienced a higher social impact}

The incremental benefits reported by the SHGs included increased level of income, improved production skills and improved ability to deal with risks. Some of the benefits reported as a result of increased income included increased levels of income, better housing, improved health access, better children's education, improved sanitation, better access to energy, improved food security and enhanced social status. Empowerment related benefits included increased decision making in household, improved level of financial decision making, better decision making on livelihood issues, improved social mobility, improved social status, widened spaces for expressing views. There was a reportage of initiating agriculture allied enterprises. 
There were instances where children who normally used to dropout by $8^{\text {th }}$ standard in IGS federation areas, started going for ITI, Diploma or Polytechnic education. Similarly in the case of health, social intermediary services such as on health awareness camps by IGA and APM on HIV, Pulse Polio, food and nutrition resulted in diagnosis of problems and addressing the same on a timely basis.

\section{SHG federations was in need of capacities in delivering livelihood services}

For an SHG federation to perform the role of livelihood promoter, it needs to provide services related to productivity enhancement, input-output linkages, value addition, risk management, skill building, business advice and others. It also needs to have capacities for providing such services. However, members pointed to larger gaps in services. Even in relation to credit services, they did not receive sufficient credit. They felt the need to have extension services, skill development, and entrepreneurship development services and marketing though demand for more credit was the highest.

SHG federations were found to be primarily offering financial intermediation and capacity building services. Livelihood services were few and far between and were add on services rather than institutionalised services. There were a few (about one-fourth) federations which were offering livelihood advisory services, extension services, market linkages and vocational skill building services. These services were found to be useful for the SHGs and SHG members. However, the desire for credit services outpaced the demand for any other livelihood services by the SHG members. SHG members were found to be largely demanding credit services followed by skill development and support for enterprise

development. From the limited number of sample of SHG federations that were observed it was found that they were lacking capacities to offer livelihood services in an institutionalized manner.

\section{Focus on sustainability is lower}

Federations were found to be very lowly focused on attaining sustainability. Most of them were far away from attaining financial sustainability. Though there were federations which were doing well in financial sustainability parameters, it failed on other parameters such as institutional sustainability. E.g., BVS in Chanderi is involved in weaving activity. By delivering orders to big retailers, it makes decent profit. It also adds to this profit by selling curtains, ladies suit, dupatta, table covers and others in trade fairs. However, it was doing badly in terms of institutional sustainability as it was not following basic norms of governance. From the institutional perspective, influence of the promoting agency was found to be higher. There were instances of interference of promoting agency.

Lack of financial sustainability was also due to lack or low scale of non-financial production activities. E.g., Vikramanagala federation has facilitated establishment of garment manufacturing unit in the village with infrastructure and machinery provided by promoting agency. However, production levels are too low in this case for it to become sustainable.

An important dimension of sustainability is also the legal and regulatory framework. Panchayat level federation being a society cannot take up commercial activity.

There tended to be focus on social sustainability with focus on offering social services such as health, education, nutrition, women development services and building long term linkages with government departments, developmental agencies such as NABARD, agriculture and horticulture department, health department, education department etc.

\section{SHGs were relatively autonomous}

In none of the SHGs surveyed, it was found that federations are affecting the SHG autonomy. All the SHGs which are associated with the federation are of the view that their association with the federation is not burdensome and these federations actually complement their quest of development. Even SHGs which 
are not part of the federation did not cite that 'membership in SHG federation restricts choices' as the reason for not being part of it.

The SHGs were found to be relatively autonomous in making decisions related to SHG operations. These could be related to its internal rate of lending, savings amount, periodicity of SHG meetings, pattern of distribution of loans, decisions on beneficiaries, offering of any specialized services or activities it would like to take up. SHGs found that the federations were beneficial as they added a layer in its list of supportive institutions it can approach. SHG federations ensured that the SHGs develop linkages with institutions such as banks, government departments and other resource agencies for getting benefit from these financial and technical institutions. SHGs expressed that federations were complementary to their growth and progress. Even in instances when SHG federation wanted uniform norms to be set up, the decisions were taken in a democratic manner. SHG members views were represented in the federation. Autonomy ensured that SHGs were flexible in developing their own norms according to the specific situations.

\section{High focus on financial services prevents moving into livelihood approach}

None of the SHG federations studied in Tamil Nadu and Madhya Pradesh are into provision of multiple livelihood promotion services. While IGS, VCLF, APAM, SJRC and NSMS have partly made their efforts in rendering livelihood services with the support of their promoting agencies and other federations engaged in financial intermediation services like savings, credit and insurance the vision does not go beyond the provision of financial services. The federations are not oriented towards rendering the livelihood services on its own. The staffs are well trained to deliver the financial intermediary services and not the livelihood services. The specific livelihood services being extended mainly depend on the support that the federations receive from the government departments, donor agencies and promoting agencies.

Another challenge before the federation would be even if it wants to come out with a revenue model in offering livelihood services, whether the targeted clientele is sufficient enough to achieve the same. Hence not only the vision, but also the capacity, existence of resources, lack of guarantee regarding feasibility of livelihood intervention model impedes livelihood intervention through a cost-covering model on a sustainable basis. The focus tends to be to primarily achieve a threshold in financial services. However, self-sustainable financial delivery is not an impediment on the way of offering livelihood services.

Overall, the federations lacked the vision to see themselves as livelihood support institutions. Financial intermediation somehow restricts the ability of the federations to look beyond the financial intermediation services. While the mission of the federation need not restrict federations from performing non-financial roles, the energies tend to be largely focused towards performing financial intermediary services. In the absence of other financial access services, need for credit seems to be the most important requirement. Federations are guided by the need for 'Minimalist Credit Approach'. Federations seemed to be less interested in building their institutions as livelihood support organizations. There was absence of any specialized staff for offering other livelihood support services. Even the federations which too some extent is into offering livelihood services are not willing to plunge into value chain approach to livelihood promotion. In relation to social intermediation services, the old timers were primarily guided by social intermediary services while the newly recruited more focused on financial services.

\section{Section 5: Key Policy Recommendations}

To emerge as quality federations which are also into livelihood promotion, SHG federations need to overcome some of its inherent weaknesses. The quality of SHG federations seemed to be affected by lack of demarcation in responsibilities between governing board and the promoting agency, governing board and the management, lack of accounting systems, lack of institutionalization of norms in its relationship 
with SHGs. To address this, there is need to develop uniform norms, strengthening democratic practices, strengthening governance, building institutional structures for multiple services, strengthening intermediary institutions, building robust accounting and internal control systems, creating management information systems (MIS) and deploying quality human resources. For effective self-management, there is need to provide primacy to autonomy of the federation and encouraging participation of members.

Committees within federation

SHG federations also combine a variety of roles into one - financial intermediary, social intermediary and livelihood promotion. A single structure to perform multiple roles is found as a difficulty for SHG federations. Introduction of different committees to take care of the multiple needs of the SHG federations can go a long way for SHG federations to perform the same. This will mean that SHG federations will have a separate financial inclusion committee, social intermediation committee and livelihood promotion committee. As SHG Federations mature and take on more roles, the structure should be flexible to govern and manage all these functions. Introduction of different committees to take care of the multiple needs of the SHG federations is necessary.

Contract works for implementing government programs

Policy which encourages SHG federations to directly take up contract works in relation to implementation of social intermediary and livelihood intermediary functions (like NGOs) from agencies can be useful. This could be related to social functions of government such as public distribution system, insurance provisioning, old age pensions, housing etc. and livelihood functions such as implementation of NREGA etc.

Diversification of financial sources for financial sustainability

The resources that the Federation generates (plans to generate) should have a mix of share capital, savings, membership fee, interest/ commission on services, service charges and monitoring fees. The capital base of SHG federations at present is limited. A policy which encourages it to expand its capital base through inclusion of new streams such as public donations, corporate funds, CSR funds, and grant funds directly from donor agencies can be useful.

Rating system to promote sustainability

Institutional sustainability is the pattern of governance within federation and the extended role of the promoting agency. Though guidelines suggest and emphasize rotational leadership, there have been instances of continued role of dominant leaders within federation and extended role of promoting agency in decision making. A rating system of SHG federations needs to be developed which emphasizes on succession planning (for rotational leadership) to be introduced in the federation. A rating system with higher weightage to institutional sustainability dimensions (practice of rotational leadership / succession planning and federation takeover of NGO role) can assist in promoting dimensions of institutional sustainability within federations. A rating system with weightage on institutional sustainability over financial sustainability and making rating mandatory every two years which gets integrated into the lending and other decisions to SHG federations can help in building institutional sustainability in SHG federations.

Encouraging transition from primarily financial intermediaries to livelihood support organizations

While SHG federations may during the initial years primarily act as financial intermediaries, in the long term this role need to be transferred to banks. SHG federations with support of promoting agencies and NABARD may sensitize the banks to play a more active role in lending to SHGs even in non-southern states as in southern states banks have been comparatively doing well in lending to SHGs. While 
continuing to partly handle financial intermediary role, this role needs to be reduced in favor of providing livelihood support services.

Inbuilt capacity building components as LSOs into the withdrawal Strategy

An inbuilt capacity building component as LSOs needs to be an integral part of the withdrawal strategy. Promoting agencies should aim to increase federation's role beyond financial intermediaries into that of livelihood support organizations. This would mean that it needs to invest resources in orienting federations in varied dimensions of livelihood promotion - identification of livelihoods, value chains, micro-enterprise development, product management, marketing, business planning and management etc. NABARD should provide grants to promoting agencies for capacity building of federations as LSOs.

Creating SHG Federation capacity building fund with NABARD

A separate SHG federation fund needs to be created under NABARD which funds directly to SHG federations. A division within NABARD needs to look into the same. The funds could be both of grant cum credit nature. The division could: a) process requests by SHG federations for lending support for livelihood and social purposes; b) evaluating the feasibility of the lending proposals; c) onsite visits to SHG federations; d) holding meetings of loan sanctioning committee; e) approval of the loans based on potential benefits from the projects; f) monitor loan usage by SHG federations etc.

The District Development Manager (DDM) could be the key person at District level that would review the proposals by SHG federations and forward the same to SHG federation fund division. It shall review the forwarded proposal by DDM with her / his comments and thus take decisions on lending issues.

The purpose for lending SHG federations could be for multiple purposes: on-lending to SHGs (in remote areas), for undertaking production and marketing activities, for construction of socially relevant infrastructure such as community halls where livelihood activities can be carried out, direct engagement in livelihood activities for aggregation and storage of produce, processing activities etc.

The following Policy takeaways are recommended based on the findings of the study.

\section{Eligibility Conditions for the formation of a Federation}

- There should be a clear expression of demand by the SHGs (no top-down target driven approach; only bottom-up organic approach)

- Establishment and registration of a Federation should be done only after a thorough institutional assessment that envisages institutional and financial sustainability over a period of time

- A participatory process must be mandated in the formation of the Federation where SHG members and office bearers are involved, to ensure and imbibe a sense of ownership. Mobilization of resources both financial and human resources from within the SHGs should be encouraged and supported

\section{Functions of a Federation}

- Promotion of new SHGs and facilitating training of SHG leadership and management functionaries.

- To offer financial intermediation services to SHGs under these circumstances:

- Geographical areas where the SHG Bank linkage program is not functional (weak or ineffective) 
- The quantum of credit being accessed by SHGs from the Banks under the SHG BLP is inadequate

Corollary: The Federation should not offer competing financial services to its constituent SHGs, placing them in a catch-22 situation

- Implementation of Livelihood Promotion Schemes of the Government/ Government departments. A circular to this effect that gives legitimacy and recognizes the identity of SHG federations to play the role of Livelihood Promotion Organizations

- Policy which encourages SHG federations to directly take up contract works in relation to implementation of social intermediation and livelihood intermediation functions (like NGOs) from agencies can be useful. This could be related to social functions of government such as public distribution system, insurance provisioning, old age pensions, housing etc. and livelihood functions such as implementation of NREGA, partnership in NRLM schemes etc.

\section{Structure and Governance}

- A policy guideline encouraging the setup of a financial inclusion committee, social intermediation committee and livelihood promotion committee as board committees

- A democratic means and system to evolve leadership from the SHGs and secure mechanisms to ensure rotation of leadership

- Regular meetings, Annual General Body meetings and compliance with regulatory aspects to be maintained (in alignment with the nature of incorporation of the Federation)

- A system for the rating of SHG federations emphasizing on succession planning (for rotational leadership) to be introduced in the federation, with weightage on institutional sustainability over financial sustainability and making rating mandatory every two years which gets integrated into the lending and other decisions to SHG federations

\section{Resources}

The policy guideline should mandate SHG Federations to have a mix of share capital, savings, membership fee, interest/ commission on services, service charges and monitoring fees. SHG Federations can also expand its capital base through inclusion of new streams such as public donations, corporate funds, CSR funds, and grant funds directly from donor agencies.

\section{Policy recommendations for SHGs}

NABARD should ensure that the banks participating in the SHG Bank Linkage program follow the existing policy guidelines and circulars related to SHG Bank Linkage program

- Cash credit limits for SHGs

The NABARD SHG2 Circular ${ }^{2}$ clearly articulates the need for banks to sanction cash credit / overdraft based system of lending for SHGs. However in all of the 20 Federations studied we did not find a single instance of this. Hence the guidelines may be made clearer to the participating banks to encourage this.

\footnotetext{
${ }^{2}$ Circular No:65 (A)/MCID-04/2011-12
} 
- Ratio of savings to credit: As per the guidelines, banks are encouraged to increase the limit of bank lending to SHGs over a period of time- from 1:1 to 1: 4 and 1:10 also. As a result of insufficient credit from banks and the method of equal distribution of loan, members are receiving less credit than their requirement. Members who borrow less than adequate amount as loan either borrows the deficit from costlier and less transparent private sources or worse still, deploys the money to cover some other non-economic expenses. Indebtedness increases with no significant improvement in asset base. It is more efficient if the lending norms are established after more local consultation with federated structure and the NGO (if any) and the NGOs made more accountable.

\section{Proposed trajectory for emergence of SHG Federations as LPOs}

The SHG federation need to follow a path as depicted in the growth trajectory which shows the growth phases a typical SHG Federation with recommended timeframe. The changing role of the Federation over the years in tandem with that of the Promoting NGO (which changes from doer to facilitator), the products and services, the systems, management aspects, governance and sustainability aspects are presented here. The support necessary from NABARD to effect this transformation is also indicated.

\begin{tabular}{|c|c|c|c|}
\hline & $\begin{array}{c}\text { Nascent } \\
\text { (Time: } 0 \text { to } 2 \text { years) }\end{array}$ & $\begin{array}{c}\text { Emergent } \\
\text { (Time: } 2 \text { to } 5 \text { years) }\end{array}$ & $\begin{array}{c}\text { Mature } \\
\text { (Time } 5 \text { and above) }\end{array}$ \\
\hline 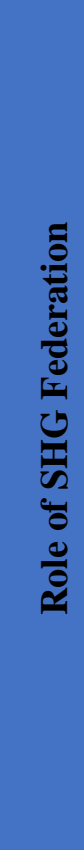 & $\begin{array}{l}\text { - } \begin{array}{c}\text { Focus primarily on } \\
\text { financial intermediation }\end{array} \\
\text { - } \quad \text { Formation of SHGs }\end{array}$ & $\begin{array}{l}\text { Financial intermediation } \\
\text { + Facilitation of SHG-bank } \\
\text { Linkage } \\
\text { - Formation, nurturing, } \\
\text { grading and auditing of } \\
\text { SHGs } \\
\text { - } \begin{array}{l}\text { Identification and Action } \\
\text { to be taken on social issues }\end{array} \\
\text { Identification of } \\
\text { livelihood related needs of } \\
\text { SHG members and start } \\
\text { collective livelihood } \\
\text { activities } \\
\text { Generate awareness on } \\
\text { govt. schemes and } \\
\text { programs and process of } \\
\text { claiming entitlements. }\end{array}$ & $\begin{array}{l}\text { Financial } \\
\text { intermediation only when } \\
\text { absolutely necessary } \\
\text { - Livelihood activities, } \\
\text { market linkages, } \\
\text { facilitating input-output } \\
\text { linkages } \\
\text { Training on financial } \\
\text { literacy }\end{array}$ \\
\hline
\end{tabular}




\begin{tabular}{|c|c|c|c|}
\hline 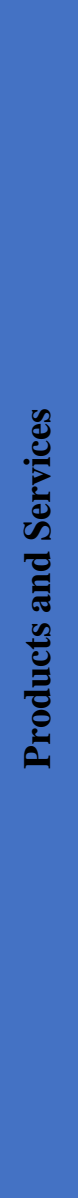 & $\begin{array}{l}\text { - Financial Services } \\
\text { largely savings and credit } \\
\text { - Data sharing with banks } \\
\text { to be initiated } \\
\text { - Compulsory savings by } \\
\text { the members should be } \\
\text { focussed on }\end{array}$ & $\begin{array}{l}\text { Financial Services } \\
\text { (Savings, credit, Insurance, } \\
\text { diversification of loan } \\
\text { products) } \\
\text { - Non-financial Services } \\
\text { (rights and entitlements) } \\
\text { - Institutional linkages with } \\
\text { livelihood players }\end{array}$ & $\begin{array}{l}\text { Financial services } \\
\text { (broad range of savings, } \\
\text { recurring and fixed } \\
\text { deposits, insurance and } \\
\text { pensions, different kinds } \\
\text { of loans - livelihood } \\
\text { related loans) } \\
\text { Livestock and } \\
\text { Agriculture extension } \\
\text { services (direct / indirect) } \\
\text { Business and Micro- } \\
\text { enterprise development } \\
\text { advisory services } \\
\text { Market linkage and } \\
\text { Value addition services } \\
\text { Storage and Value } \\
\text { addition services } \\
\text { Skill development and } \\
\text { vocational training } \\
\text { Implementation of } \\
\text { government schemes - } \\
\text { social programs } \\
\text { including income } \\
\text { generation }\end{array}$ \\
\hline 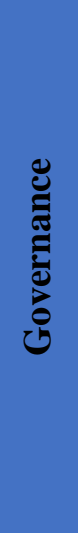 & $\begin{array}{l}\text { Board members are } \\
\text { new and dependence on } \\
\text { promoting agency is high } \\
\text { Board members not } \\
\text { aware of their roles and } \\
\text { responsibilities }\end{array}$ & $\begin{array}{l}\text { Initiating board meeting } \\
\text { on a regular basis } \\
\text { - } \quad \text { Influence of promoting } \\
\text { agency is reduced in } \\
\text { decision making } \\
\text { - } \quad \text { Rotation of board } \\
\text { members is initiated } \\
\text { Compliance with } \\
\text { statutory processes }\end{array}$ & $\begin{array}{l}\text { Full-fledged governing } \\
\text { board, regular board } \\
\text { meetings, well informed } \\
\text { members, autonomy in } \\
\text { decision making } \\
\text { Rotation of board } \\
\text { members in compliance } \\
\text { with the norm } \\
\text { Nil influence or at best, } \\
\text { promoter agency only in } \\
\text { advisory role }\end{array}$ \\
\hline
\end{tabular}




\begin{tabular}{|c|c|c|c|}
\hline 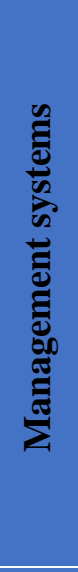 & $\begin{array}{l}\text { - } \begin{array}{l}\text { System should aim at } \\
\text { evolving }\end{array} \\
\text { - } \quad \text { Strong mechanism to } \\
\text { ensure members } \\
\text { involvement } \\
\text { - Operational processes } \\
\text { should be hand-held }\end{array}$ & $\begin{array}{l}\text { Professional staff is be } \\
\text { hired and trained to work } \\
\text { in the federation } \\
\text { Setting up MIS and } \\
\text { accounting systems } \\
\text { Starting-off financial and } \\
\text { livelihood activities }\end{array}$ & 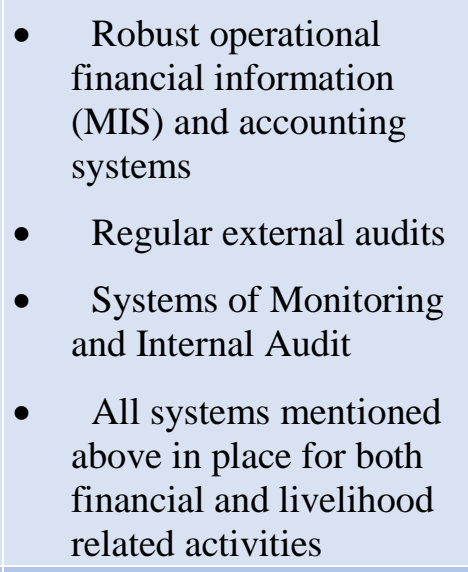 \\
\hline 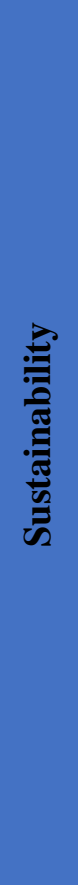 & $\begin{array}{l}\text { Developing a strong } \\
\text { support base } \\
\text { - Should aim at } \\
\text { increasing in the number } \\
\text { of clientele, savings, } \\
\text { recovery rate } \\
\text { - Continuous support by } \\
\text { promoter agencies }\end{array}$ & $\begin{array}{l}\text { Institutional sustainability } \\
\text { should involve a process of } \\
\text { hand-holding by promoter } \\
\text { agency } \\
\text { Cultivating faith-based } \\
\text { relations with financial } \\
\text { institutions and SHG } \\
\text { members }\end{array}$ & $\begin{array}{l}\text { Institutional } \\
\text { sustainability is ensured } \\
\text { through (a) member- } \\
\text { centric products and } \\
\text { services, (b) good } \\
\text { democratic governance } \\
\text { and (c) management } \\
\text { practices } \\
\text { - Financial sustainability } \\
\text { ensured through a } \\
\text { healthy and steady mix } \\
\text { of financial resources and } \\
\text { ownership } \\
\text { Social sustainability } \\
\text { ensured through long } \\
\text { term social impact on } \\
\text { members through client } \\
\text { centric products and } \\
\text { services }\end{array}$ \\
\hline
\end{tabular}




\begin{tabular}{|c|c|c|c|}
\hline $\begin{array}{l}0_{0}^{\infty} \\
\sum_{1}^{1} \\
\frac{0}{0} \\
\frac{0}{0}\end{array}$ & $\begin{array}{l}\text { - } \begin{array}{c}\text { Guide the federation } \\
\text { formation process }\end{array} \\
\text { - } \quad \text { Training to office } \\
\text { bearers, community } \\
\text { cadre } \\
\text { - Bank account be } \\
\text { opened } \\
\text { - } \quad \text { Institute mechanisms to } \\
\text { assess the quality of } \\
\text { SHGs } \\
\text { Conduct training needs } \\
\text { assessment for SHGs and } \\
\text { organise the required } \\
\text { training programmes }\end{array}$ & $\begin{array}{l}\text { At this stage, a } \\
\text { demarcation of boundaries } \\
\text { between the NGOs and the } \\
\text { board and management of } \\
\text { federation should be } \\
\text { maintained } \\
\text { Division of } \\
\text { responsibilities should be } \\
\text { made clear and pushing the } \\
\text { federation to fund raising } \\
\text { activities for themselves to } \\
\text { be initiated } \\
\text { Initiate insurance, } \\
\text { pension schemes, etc. }\end{array}$ & 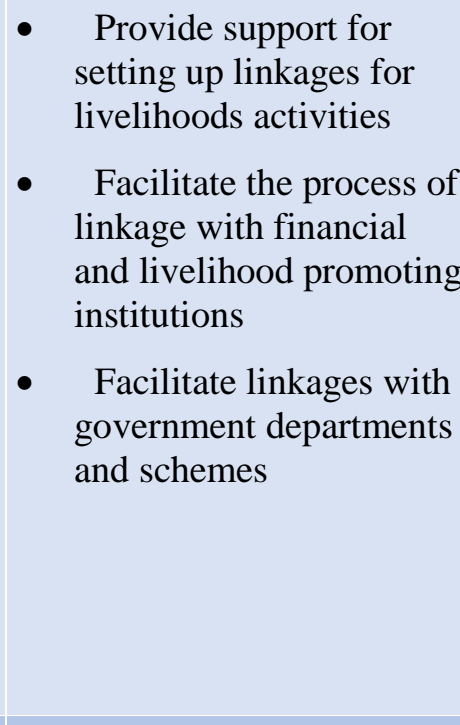 \\
\hline 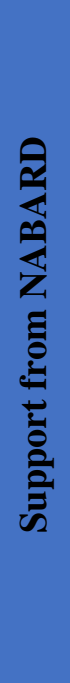 & $\begin{array}{l}\text { Funds like capacity } \\
\text { building for NGOs to } \\
\text { support federations to } \\
\text { move to the emergent } \\
\text { stage from the nascent } \\
\text { stage }\end{array}$ & $\begin{array}{l}\text { Convergence with } \\
\text { various schemes available } \\
\text { to federations } \\
\text { Capacity building funds } \\
\text { to be provided to } \\
\text { federations } \\
\text { Funds for trainings on IT, } \\
\text { MIS, financial and } \\
\text { livelihood management } \\
\text { systems } \\
\text { Grant funds to federations } \\
\text { for inculcating in them } \\
\text { capacities as livelihood } \\
\text { support organisations }\end{array}$ & $\begin{array}{l}\text { Funds from NABARD } \\
\text { to initiate exposure visits } \\
\text { by the promoting agency } \\
\text { to the federation, along } \\
\text { with funds for leadership } \\
\text { training } \\
\text { Provide grant cum } \\
\text { credit support for SHG } \\
\text { federations for } \\
\text { undertaking livehood } \\
\text { support services }\end{array}$ \\
\hline
\end{tabular}

\section{Conclusion}

It can be concluded by stating that SHG federations have come to occupy an important place in financial inclusion space in India. While this is appreciable, it needs to graduate into livelihood support organizations. While there have been guidelines for SHGs in the country, there is absence of clear cut guidelines when it comes to SHG federations. Such a set of guidelines with clear cut directions on the role and functions the federations need to take up, the processes which it needs to comply with, the sources from where it can raise capital resources, steps it needs to take for strengthening governance and participation of members, steps it needs to take for inclusion of livelihood promotion tasks etc. - all these will go a long way in strengthening SHG federations as livelihood support organisations. 


\section{References}

Dr. Wolfgang Salomo, G. B. (December 2012). A Study of SHG Federation Structures in India: Core elements of sustainability. New Delhi: GIZ.

NABARD. (2013). Status of Microfinance in India 2012-13. Mumbai: Micro Credit Innovations Department, NABARD.

Thankha, G. S. (2010). SHG federations: Development costs and Sustainability. New Delhi: Access Development Services. 